\title{
Staphylococcal species less frequently isolated from human clinical specimens - are they a threat for hospital patients?
}

\author{
Magdalena Szemraj $^{1 *}$ D, Magdalena Grazul ${ }^{1}$, Ewa Balcerczak² and Eligia M. Szewczyk
}

\begin{abstract}
Background: Coagulase-negative staphylococci belonging to S. haemolyticus, S. hominis subsp. hominis, S. simulans, and S. warneri are often described as etiological factors of infections. Staphylococci are a phylogenetically coherent group; nevertheless, there are differences among the species which may be important to clinicians.

Methods: We investigated selected virulence factors and antibiotic resistance that were phenotypically demonstrated, the presence and expression of genes encoding the virulence factors, and the type of the SCCmec cassette.

Results: The differences between the tested species were revealed. A great number of isolates produced a biofilm and many of them contained single icaADBC operon genes. Clear differences between species in the lipolytic activity spectrum could be related to their ability to cause various types of infections. Our studies also revealed the presence of genes encoding virulence factors homologous to $S$. aureus in the analysed species such as enterotoxin and pvl genes, which were also expressed in single isolates of S. simulans and S. warneri. S. haemolyticus and S. hominis subsp. hominis isolates were resistant to all clinically important antibiotics including ß-lactams. The identified SCCmec cassettes belonged to IV, V, VII, and IX type but most of the detected cassettes were nontypeable. Among the investigated species, $S$. hominis subsp. hominis isolates accumulated virulence genes typical for $S$. aureus in the most efficient way and were widely resistant to antibiotics.
\end{abstract}

Conclusions: Our results clearly indicated significant differences between the tested species, which might be a result of the horizontal gene transfer (HGT) and can lead to the formation and selection of multi-drug resistant strains as well as strains with new virulence features. Such strains can have a new clinical relevance.

Keywords: CoNS virulence, Staphylococcus hominis, Genes transfer

\section{Background}

The clinical relevance of coagulase-negative staphylococci (CoNS) belonging to Staphylococcus haemolyticus, S. hominis, S. simulans, and S. warneri species is increasing. The appearance of automated identification systems improved their detection. Although staphylococci constitute a phylogenetically coherent group there are differences among the species important to clinicians [1].

According to the literature, S. haemolyticus is the second major species among CoNS responsible for health

\footnotetext{
* Correspondence: magdalena.szemraj@umed.lodz.pl

'Department of Pharmaceutical Microbiology and Microbiological Diagnostic, Medical University of Lodz, Pomorska 137, 90-235 Łódź, Poland

Full list of author information is available at the end of the article
}

care associated infections [2, 3]. It causes blood infections, sepsis, and is often isolated from ocular infections [4]. It is also detected as a cause of otitis, peritonitis, and urinary tract infections [5]. It is noteworthy to mention that $S$. haemolyticus is known as a species easily acquiring resistance genes. Therefore, most strains belonging to this species are resistant to available antimicrobial agents $[6,7]$.

Another CoNS that may be a threat to humans is $S$. hominis. It is described as the third most often isolated species from patients' blood infections [8]. MendozaOlazaran et al. (2013) claimed that its isolates from blood commonly produced a biofilm and that they were often methicillin-resistant [9]. Pathogenicity of S. hominis is

(C) The Author(s). 2020 Open Access This article is distributed under the terms of the Creative Commons Attribution 4.0 International License (http://creativecommons.org/licenses/by/4.0/), which permits unrestricted use, distribution, and reproduction in any medium, provided you give appropriate credit to the original author(s) and the source, provide a link to the Creative Commons license, and indicate if changes were made. The Creative Commons Public Domain Dedication waiver (http://creativecommons.org/publicdomain/zero/1.0/) applies to the data made available in this article, unless otherwise stated. 
usually revealed with hospital-acquired bacteraemias as a result of medical procedures [10].

In the literature, S. epidermidis and S. aureus are described as the most common causes of prosthetic joint infections (PJIs), that are one of the most serious complications of prosthetic surgery associated with significant morbidity, but case studies related to $S$. hominis and S. haemolyticus as the main factors of this type of infections were also reported [11-13]. S. hominis infection can also lead to endophthalmitis associated with a capsular hypopyon [14].

It was postulated that $S$. simulans is rather an animal species, which rarely colonizes the human organism. Despite this, S. simulans is referred to as a cause of osteomyelitis, prosthetic joint infections as well as a habitant of the urinary tract of healthy women $[15,16]$. Clinicians, especially dermatologists, should be aware that $S$. simulans can cause skin and soft tissue infections; therefore, it should not be treated as a sample contamination $[17,18]$. Moreover, it is suggested that $S$. simulans is more virulent than other CoNS and leads to infections clinically similar to those caused by $S$. aureus $[18,19]$.

According to Torre et.al. (1992), one of the first S. warneri isolates came from monkey skin and nasal membranes [20]. The first isolations of this species from humans were related to implant-associated infections. It is postulated that $S$. warneri rarely causes infections in individuals that are free from risk factors such as endovascular prosthetic devices or catheters. Nevertheless, there are some case reports of $S$. warneri sepsis e.g. in immunocompetent patients with multiple abscesses [21]. It can also cause infections related to community-acquired native valve endocarditis even in patients apparently free from underlying valvular heart disease and haematogenous vertebral osteomyelitis. This species was also detected in orthopaedic cases and bacteraemia [22, 23]. It is reported that it is the next species after S. epidermidis that colonizes hands of nurses and neonatologists, and more than $80 \%$ of its strains were resistant to methicillin [23]. S. warneri is one of the predominant novobiocin-sensitive CoNS species inhabiting the skin of healthy humans [24]. Similarly to S. epidermidis and S. haemolyticus, S. warneri may be responsible for urinary tract infections and its presence can be associated with cellular changes in the bladder [5]. Furthermore, according to the literature, S. epidermidis is considered as the most common CoNS species isolated from human infections $[25,26]$. As other species are rarely described as etiological factors of infections, the characteristics of virulence and resistance of these species are not completely known.

In our study, we used 80 clinical CoNS isolates of $S$. haemolyticus, S. hominis, S. simulans, and S. warneri species. The aim of our study was to detect the differences between the tested species; therefore, we examined the phenotypically demonstrated virulence factors, SCCmec cassette typing as well as the presence and expression of genes homologous to $S$. aureus that encoded the virulence factors. The data related to the differences among these species, their virulence factors as well as mechanisms of antibiotic resistance can lead to a better understanding of CoNS infections and thus improve the clinical prognosis and suggest an efficient treatment.

\section{Methods}

\section{Tested strains}

A total of 80 clinical CoNS isolates were involved in our studies: 23 S. haemolyticus isolates, $20 \mathrm{~S}$. hominis isolates, $18 \mathrm{~S}$. simulans isolates, and $19 \mathrm{~S}$. warneri isolates. All isolates tested in the study were obtained by a diagnostic microbiology laboratory (Synevo Sp. z o.o.) of Lodz area, Poland during 2014-2016. All S. hominis isolates as well as six isolates of $S$. haemolyticus came from blood. Other $S$. haemolyticus and S. simulans isolates came mostly from infected wounds, while $S$. warneri from many different sites e.g. from the eye, the peritoneum, wounds, and the urethra.

The isolates were identified using the MALDI-TOF method as well as a genetic technique [27, 28]. S. haemolyticus ATCC 29970, S. hominis subsp. hominis ATCC 27844, S. warneri ATCC 27836 and S. simulans ATCC 27848 were used as the control in the PCR identification tests.

\section{Characterisation of the virulence factors of the tested isolates}

The biofilm formation was evaluated with the crystalline violet $(\mathrm{CV})$ staining method after $24 \mathrm{~h}$ of cultivation at $37^{\circ} \mathrm{C}$ in 96 -well polystyrene plates under the static condition as described by Christensen et al. (1985) [29]. The ability to produce lipases was determined on a medium with the addition of triolein (ICN Biomedicals) [30] and on an agar medium supplemented with $1 \%$ of Tween 20 , Tween 40, Tween 60, Tween 80 and Tween 85, respectively (ICN Biomedicals). The cultures on the Tween media were incubated for $18 \mathrm{~h}$ at $37^{\circ} \mathrm{C}$ followed by a further 24-h incubation at a room temperature. Insoluble calcium soaps, which were visible in the form of turbidity around the growth zone, proved the enzymes activity. $S$. aureus ATCC 12600 reference strain was used as a control. The haemolytic activity of cytolysins was determined on an agar medium with $5 \%$ of sheep blood. The production of $\beta$-toxin was detected by a reverse CAMP test and an analysis of the hot-cold effect. The production of $\delta$ toxin was detected by the CAMP test.

\section{The detection of phenotypic resistance to antibiotics}

The sensitivity to antibiotics was determined by the discdiffusion method (using Becton Dickinson discs) in accordance with the EUCAST guidelines. The sensitivity to the following antibiotics: cefoxitin (FOX-30), clindamycin 
(CC-2), erythromycin (E-15), gentamicin (GM-10), tetracycline (TE-30), ciprofloxacin (CIP-5), tigecycline (TGC15), linezolid (LZD-30), cotrimoxazole (SXT-1.25/23.75), rifampicin (RA-5), and fusidic acid (FA-10), has been examined. S. aureus ATCC 29213 was used as a control strain. The results were interpreted according to the EUCAST guidelines. For LZD-30, which is not covered by EUCAST, the CLSI guidance was used.

\section{DNA and RNA isolation}

The genomic DNA, used further for the DNA analysis, was isolated using the Genomic Micro AX Staphylococcus Gravity set (A\&A Biotechnology, Poland) concordantly with the protocol provided by the manufacturer. RNA was isolated by the Total RNA Prep Plus Minicolumn Kit (A\&A Biotechnology, Poland) according to the protocol provided by the manufacturer.

\section{An SCCmec analysis by PCR}

The presence of the mecA gene was determined by PCR [31]. S. epidermidis ATCC 51625 was used as a control. PCR assays for typing of SCCmec cassettes were executed according to methods described by Kondo et al. (2007) and Zhang et al. (2005) in which specific types of the $c c r$ gene complexes $(A B 1, A B 2, A B 3$ or $C)$ and the mec gene complexes $(A, B$ and $C$ ) were looked for [31, 32]. The ccrAB4 gene was determined using the method proposed by Oliveira et al. (2006) with some modifications according to Zhang et al. (2013) $[33,34]$. The cassettes in which the determination of the $c c r$ and/or mec gene complex by PCR assays was not possible, were identified as "non-typable" (NT), while the cassettes that contained a previously undefined combination of these genes were classified as not yet detected (NEW) according to the principles established by the International Working Group on the Classification of Staphylococcal Cassette Chromosome Elements (2009) [35].

The detection of the enterotoxins and haemolysin genes as well as genes encoding enzymes responsible for the PIA production (the ica operon genes)

The presence of the following genes was determined: 1 . genes encoding enterotoxins: sea (520 bp), seb (643 bp), seg (327 bp), sei (465 bp); 2. genes encoding haemolysins: hla (209 bp), hlb (309 bp), hld (111 bp), $\gamma$-haemolysin component A ( $h l g A ; 535 \mathrm{bp}), \gamma$-haemolysin component B ( $h l g B$; $390 \mathrm{bp}) ; 3$. genes encoding leukocidin Panton Valentine ( $p v l$; $433 \mathrm{bp}$ ); 4 . genes encoding enzymes responsible for the PIA production - the ica operon (icaA - $103 \mathrm{bp}$, icaD $198 \mathrm{bp}, i c a B-302 \mathrm{bp}, i c a C-400 \mathrm{bp}$, icaR - $469 \mathrm{bp}$ genes). PCR assays for the detection of haemolysins and Panton Valentine leukocidin $p v l$ genes were performed using the primers and parameters described by Jarraud et al., (2002) or Ünal and Çinar (2012), respectively [36, 37]. PCR assays for the detection of the ica operon genes was performed using the primers and parameters described by Arciola et al. (2005) [38]. S. aureus ATCC25923, and S. epidermidis ATCC12228 strains were used as the positive and negative controls.

\section{The analysis of the expression of the $p v l$ and sea genes}

The analysis of the expression of the $p v l$ and sea genes was executed by a real-time PCR assay on the RotorGene $^{\mathrm{Tm}} 6000$ thermocycler (Corbett Life Science; Qiagen). PCRs are set up using cDNA derived from the input RNA. Reverse transcriptase (RT) reaction was performed using Enhanced Avian HS RT-PCR Kit (Sigma) in accordance with the manufacturer's protocol.

The PCR assay mixture for PCR amplification contained the cDNA template, $0.5 \mu \mathrm{M}$ of each primer, $10 \times$ AccuTaq Buffer, 0.5 U of AccuTaq LA DNA Polymerase Mix, $0.2 \mathrm{mM}$ of each dNTP, and water to a final volume of $20 \mu$ l. Negative control was included in each experiment (a sample without a cDNA template). The primer sequences for both genes were planned using Primer3 software (sea Forward: CCTTTGGAAACGGTTAAAACG, sea Reverse: TCTGAA CCTTCCCATCAAAAAC, $127 \mathrm{bp} ; p v l$ Forward: ATCATT AGGTAAAATGTCTGGA, $p v l$ Reverse: GCATCAAGTG TATTGGATAGCAA, $179 \mathrm{bp})$.

\section{The statistical analysis}

The associations between the results obtained for species vs cassettes type, isolation, the virulence factors prevalence were determined using the chi-squared test. $P<0.05$ proved the significance of these relations. To analyse the differences between the tested species, the non-parametric Kruskal Wallis test was used.

\section{Results}

The results related to the features potentially important to the colonization and invasiveness of the tested species are presented in Table 1. The biofilm formation was phenotypically observed in $84 \%$ of investigated isolates and was statistically more common in species isolated from blood (S. haemolyticus and S. hominis) than from a wound $(p$-value $=0.02)$.

$S$. haemolyticus and $S$. hominis isolates demonstrated a hydrolytic activity against triolein (triglyceride) but only some of them produced esterases able to release fatty acids from synthetic sorbitol esters. S. simulans isolates did not cause a decomposition of triolein but of hydrolysed sorbitol esters. S. warneri isolates presented the widest spectrum of lipolytic activity. Haemolysis on agar plates supplemented with sheep blood and a positive result of the CAMP test that indicate the ability to produce $\delta$ haemolysin, were demonstrated by $74 \% S$. haemolyticus and 95\% S. hominis isolates as well as 66\% S. simulans isolates and $26 \%$ S. warneri isolates. Almost all S. haemolyticus and S. hominis isolates were clinically 
Table 1 The virulence factors demonstrated phenotypically

\begin{tabular}{|c|c|c|c|c|c|c|}
\hline \multicolumn{3}{|l|}{ Virulence factors } & \multicolumn{4}{|c|}{ Species n/total (\%) } \\
\hline & & & \multirow{2}{*}{$\begin{array}{l}\text { S. haemolyticus } \\
18 / 23\end{array}$} & \multirow{2}{*}{$\begin{array}{l}\text { S. hominis } \\
18 / 20\end{array}$} & \multirow{2}{*}{$\begin{array}{l}\text { S. simulans } \\
6 / 18\end{array}$} & \multirow{2}{*}{$\begin{array}{l}\text { S. warner } \\
10 / 19\end{array}$} \\
\hline Biofilm formation & & & & & & \\
\hline \multirow[t]{6}{*}{ Lipids degradation } & Triolein & & $23 / 23$ & $20 / 20$ & $0 / 18$ & $19 / 19$ \\
\hline & Tween & 20 & $16 / 23$ & $7 / 20$ & 18/18 & $9 / 19$ \\
\hline & & 40 & $0 / 23$ & $0 / 20$ & 18/18 & $6 / 19$ \\
\hline & & 60 & $0 / 23$ & $0 / 20$ & 18/18 & 10/19 \\
\hline & & 80 & $0 / 23$ & $4 / 20$ & $18 / 18$ & $14 / 19$ \\
\hline & & 85 & $0 / 23$ & $4 / 20$ & 18/18 & 19/19 \\
\hline \multicolumn{3}{|c|}{ Haemolysis ( $\beta$-type) on sheep blood medium } & $19 / 23$ & $18 / 20$ & $12 / 18$ & $5 / 19$ \\
\hline \multirow[t]{2}{*}{ Haemolysins } & \multicolumn{2}{|c|}{ B-haemolysin (reverse CAMP test, hot-cold effect) } & $0 / 23$ & $0 / 20$ & $0 / 18$ & $0 / 19$ \\
\hline & \multicolumn{2}{|c|}{$\delta$-haemolysin (CAMP test) } & $17 / 23$ & $19 / 20$ & $12 / 18$ & $5 / 19$ \\
\hline
\end{tabular}

resistant to beta-lactams, macrolides, lincosamides (cross-resistance), aminoglycosides as well as tetracycline, ciprofloxacin, trimethoprim/sulfamethoxazole. The isolates were sensitive to tigecycline and, with the exception of one S. haemolyticus isolate, to linezolid (Fig. 1).
A half or a little less than a half of $S$. simulans and $S$. warneri isolates were resistant to macrolides and lincosamides (cross-resistance) as well as to tetracycline. About one third (7/19) of $S$. warneri isolates was resistant to ß-lactams while six of them were resistant to

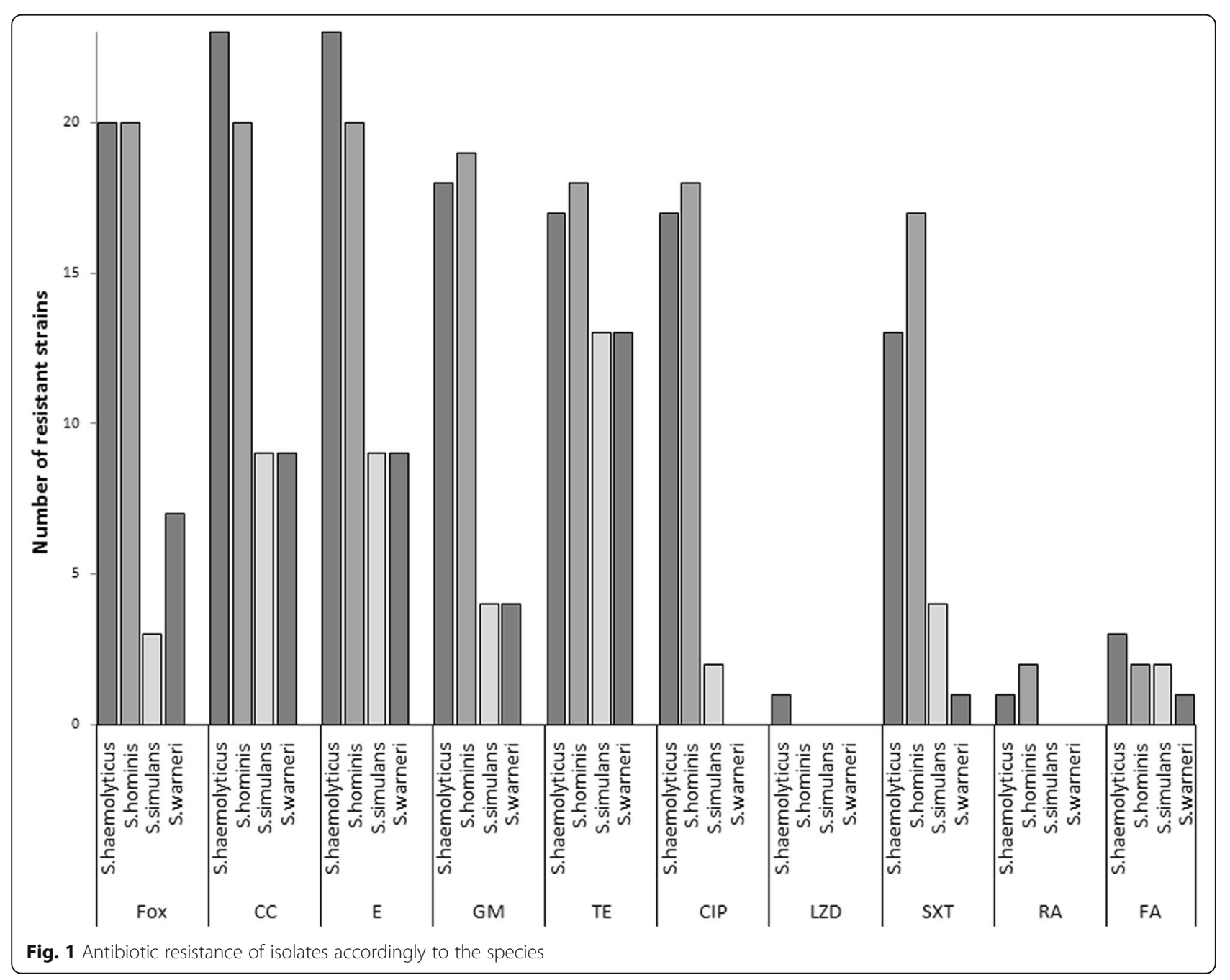


other applied antibiotics. Most of the tested isolates were sensitive to aminoglycosides and quinolones. The results presented in Fig. 1 clearly show that without a species identification, only linezolid, rifampicin, and fusidic acid can be empirically regarded as effective against the tested isolates of CoNS. The resistance to ß-lactams of all isolates with this phenotype was related to the presence of the mecA gene. This gene was located on the gene cassettes. The obtained results of the mec typing are presented in Table 2.

The majority of the detected cassettes were non-typeable. Among 19S. haemolyticus isolates with cassettes, only six were classified into class $\mathrm{V}$. The presence of this cassette was statistically significant in $S$. haemolyticus isolates ( $p$ value $=0.03$ ). Typeable cassettes in $S$. hominis species belonged to type IV, VII and IX. All methicillin-resistant $S$. simulans isolates had non-typeable cassettes while $S$. warneri had type IV cassettes (two isolates) and non-typeable cassettes (four isolates).

Searching in genomes of the tested isolates for sequences homologous to genes encoding the virulence features in S. aureus, allowed for detection of only a few of them. The obtained results are presented in Table 3. The

Table 2 Types of cassettes detected in the tested isolates

\begin{tabular}{|c|c|c|c|c|c|c|c|c|c|}
\hline \multicolumn{8}{|c|}{ scCmec cassette } & \multirow{3}{*}{$\begin{array}{l}\text { Cassette } \\
\text { type }\end{array}$} & \multirow{3}{*}{$\begin{array}{l}\text { No. of } \\
\text { isolates }\end{array}$} \\
\hline \multicolumn{5}{|c|}{ ccr complex } & \multicolumn{3}{|c|}{ mec complex } & & \\
\hline$\overline{A B 1}$ & $A B 2$ & $A B 3$ & $A B 4$ & $\bar{C}$ & $\bar{A}$ & $B$ & C & & \\
\hline \multicolumn{10}{|c|}{ S. haemolyticus } \\
\hline - & - & - & - & + & - & - & + & V & 6 \\
\hline- & - & - & - & - & - & - & + & NT & 3 \\
\hline- & - & - & - & - & - & - & - & NT & 8 \\
\hline- & - & - & - & + & + & - & - & NEW & 2 \\
\hline \multicolumn{10}{|c|}{ S. hominis } \\
\hline- & + & - & - & - & - & + & - & IV & 1 \\
\hline- & - & - & - & + & - & - & + & VII & 1 \\
\hline+ & - & - & - & - & - & - & + & IX & 2 \\
\hline+ & & - & - & + & - & - & - & NT & 2 \\
\hline- & - & - & - & - & + & - & - & NT & 6 \\
\hline- & & - & - & - & - & & + & NT & 1 \\
\hline- & - & + & - & - & - & - & - & NT & 1 \\
\hline- & + & - & - & - & - & - & - & NT & 1 \\
\hline+ & - & - & - & - & + & - & - & NEW & 3 \\
\hline- & - & - & - & + & + & - & - & NEW & 2 \\
\hline \multicolumn{10}{|c|}{ S. simulans } \\
\hline - & - & - & - & - & + & - & - & NT & 3 \\
\hline \multicolumn{10}{|c|}{ S. warneri } \\
\hline- & + & - & - & - & - & + & - & IV & 2 \\
\hline - & - & - & - & - & - & - & - & NT & 4 \\
\hline
\end{tabular}

NT non-typeable $h \lg A$ and $h \lg B$ genes encoding $\gamma$-haemolysin were detected only in $26 \%$ isolates. Single elements of icaADBC operon could not be involved in the biofilm formation.

One S. haemolyticus, one S. warneri, and two S. simulans isolates harboured the $p v l$ genes. Moreover, in one S. simulans and one $S$. warneri isolates, the sea genes were found. However, the expression of $p v l$ and sea genes was confirmed only for one $S$. simulans and one $S$. warneri isolate. None of the tested isolates exhibited an expression of both genes.

Statistically significant differences between the tested species were demonstrated in the number of genes encoding the virulence factors homologous to $S$. aureus and in the number of antibiotics that the isolates were resistant to $(p$-value $=0.04$ and $p$-value $=0.00)$.

The highest frequency of the tested genes was observed in S. hominis isolates. The isolates of that species were also resistant to the highest number of antibiotics.

\section{Discussion}

We analysed the features that are significant for the pathogenesis of four less frequently isolated CoNS species. The isolates came from the clinical material and were considered as etiological infection factors. Their relatively rare isolation provides limited data concerning the characteristic features of these species. The number of isolates analysed in our work also did not allow us to support all the obtained results by the means of a statistical analysis.

Staphylococci are a coherent group with phylogenetically close related species (Fig. 2). Such a close relation between the tested species as well as their common habitat may lead to a similar gene equipment or ability to acquire genes from related species by a horizontal gene transfer (HGT) process. The virulence factors in $S$. aureus are quite well known but the knowledge about the presence of virulence factors encoding genes and their expression and regulation in coagulase-negative staphylococci is not yet complete [41-43].

It is postulated that the pathogenicity of CoNS is related to their ability to form mixed biofilms [44, 45]. In our study, most $S$. haemolyticus as well as $S$. hominis isolates and significantly fewer isolates of S. simulans (33\%) and S. warneri (55\%) produced a biofilm. The biofilm formation by CoNS is conditioned by the presence of Microbial Surface Components Recognising Adhesive Matrix Molecules (MSCRAMMs) and the production of polysaccharide intercellular adhesin (PIA) $[46,47]$. The ability to produce polymeric $\mathrm{N}$-acetyl glucosamine (PNAG) is a result of the icaADBC operon genes activity. The icaA and icaD genes are responsible for the PIA components conformation, $i c a C$ is responsible for the elements involved in the transport of molecules outside the cell, while icaB participates in the construction of the final structure of $\mathrm{N}$-acetylglucosamine polymers that 
Table 3 Genes detected in the tested isolates

\begin{tabular}{|c|c|c|c|c|c|}
\hline \multirow[t]{2}{*}{ Gene name } & & \multicolumn{4}{|l|}{ Species } \\
\hline & & S. haemolyticus & S. hominis & S. simulans & S. warneri \\
\hline \multirow[t]{5}{*}{ Haemolysin genes } & hla & $0 / 23$ & 0/19 & 0/18 & $0 / 20$ \\
\hline & $h / b$ & $0 / 23$ & $1 / 19$ & $0 / 18$ & $0 / 20$ \\
\hline & hld & $0 / 23$ & 0/19 & 0/18 & $0 / 20$ \\
\hline & $h \lg A$ & $4 / 23$ & $8 / 19$ & $1 / 18$ & $8 / 20$ \\
\hline & $h \lg B$ & $0 / 23$ & $1 / 19$ & $0 / 18$ & $1 / 20$ \\
\hline \multirow[t]{2}{*}{ Panton-Valentine leukocidin } & $p v l$ & $1 / 23$ & $0 / 19$ & $2 / 18$ & $1 / 20$ \\
\hline & pvl expression & $0 / 1$ & $0 / 0$ & $1 / 2$ & $1 / 1$ \\
\hline \multirow[t]{5}{*}{ icaADBC operon and icaR transcriptional repressor } & $i c a A$ & $0 / 23$ & 0/19 & 0/18 & $0 / 20$ \\
\hline & $i c a B$ & $1 / 23$ & $1 / 19$ & 0/18 & $0 / 20$ \\
\hline & $i c a C$ & $5 / 23$ & $8 / 19$ & $3 / 18$ & $7 / 20$ \\
\hline & $i c a D$ & $1 / 23$ & 0/19 & $0 / 18$ & $0 / 20$ \\
\hline & $i c a R$ & $13 / 23$ & $11 / 19$ & $3 / 18$ & $9 / 20$ \\
\hline \multirow[t]{5}{*}{ Enterotoxin genes } & sea & $0 / 23$ & 0/19 & $1 / 18$ & $1 / 20$ \\
\hline & sea expression & 0/0 & 0/0 & $1 / 1$ & $1 / 1$ \\
\hline & seb & $0 / 23$ & 0/19 & 0/18 & $0 / 20$ \\
\hline & sei & $0 / 23$ & 0/19 & 0/18 & $0 / 20$ \\
\hline & seg & $0 / 23$ & 0/19 & 0/18 & $0 / 20$ \\
\hline
\end{tabular}

are already outside the cell [48-50]. Many tested isolates contained single genes from ica $A D B C$ operon but none of them harboured structure genes. It suggests the presence of another ica-independent mechanism involved in the biofilm formation. The biofilm formation by $S$. haemolyticus ica-negative ocular isolates was also confirmed by Panda and Singh (2018) [4]. The biofilm facilitates colonization, the ability to persist in the area of the infection, HGT and antibacterial drug resistance. It is noteworthy to mention that in a bacteria-forming biofilm, the production of lipase is upregulated [51, 52]. CoNS are prevalent in areas with many sebaceous follicles [53]. They grow within the sebaceous unit superficially, where they produce extracellular enzymes with lipolytic and esterolytic activity [54]. Their activity spectrum is related to the type of infections. We observed significant differences between the tested species. S. haemolyticus and S. hominis isolates from blood demonstrated lipolytic activity mostly against triolein (lipase Geh). The hydrolysis of host lipids (e.g. triolein) leads to the release of free fatty acids, crucial for the bacterial membrane phospholipid synthesis [55]. Rollof et.al. (1987) claimed that isolates from disseminated or deep infections show stronger lipolytic activity than those from superficial infection sites [56]. Regarding the fatty acid esters, the broadest spectrum in our studies was demonstrated by $S$. warneri. The samples were isolated from different materials (wound, eye, urethra, cervix). This allows us to assume that this feature helps these species to colonize a wide spectrum of niches. Isolates able to release short-chain fatty acids were detected among all the tested species. Their concentration in certain areas might be important for the microbiome formation. Free fatty acids that are released from triglycerides, together with those already present on the skin or in a wound environment e.g. from triolein, can inhibit the growth of other bacteria in the infected sites [57]. All species described in our publication displayed differences in their abilities to hydrolyse lipids. Other authors indicated that this feature is specific to the particular species [58-60]. It might predispose the species to cause a certain type of infection. The cytolysin activity expressed by staphylococci influences their virulence [61].

In our studies, almost all S. haemolyticus isolates as well as $S$. hominis isolates produced haemolysis of sheep blood. It is in opposition to the literature data, according to which S. hominis has no haemolytic activity [39]. However, this property was not related to the presence of genes homologous to those involved in haemolytic activity of S. aureus. We did not find hla or hlb genes in any of the tested isolates.

The ability to produce a two-component cytolysin $\gamma$ encoded by $h \lg A / h \lg C$ and $h \lg B$ genes is assigned to the species that cause skin abscesses [62, 63]. Among the tested isolates, S. hominis (from blood) and S. warneri (from a wound) had these genes. S. haemolyticus (from BAL), S. simulans (from a wound) and S. warneri (from the peritoneal cavity) harboured genes involved in the synthesis of Panton-Valentine leukocidin. These genes were expressed in the isolates of S. simulans and S. warneri. 


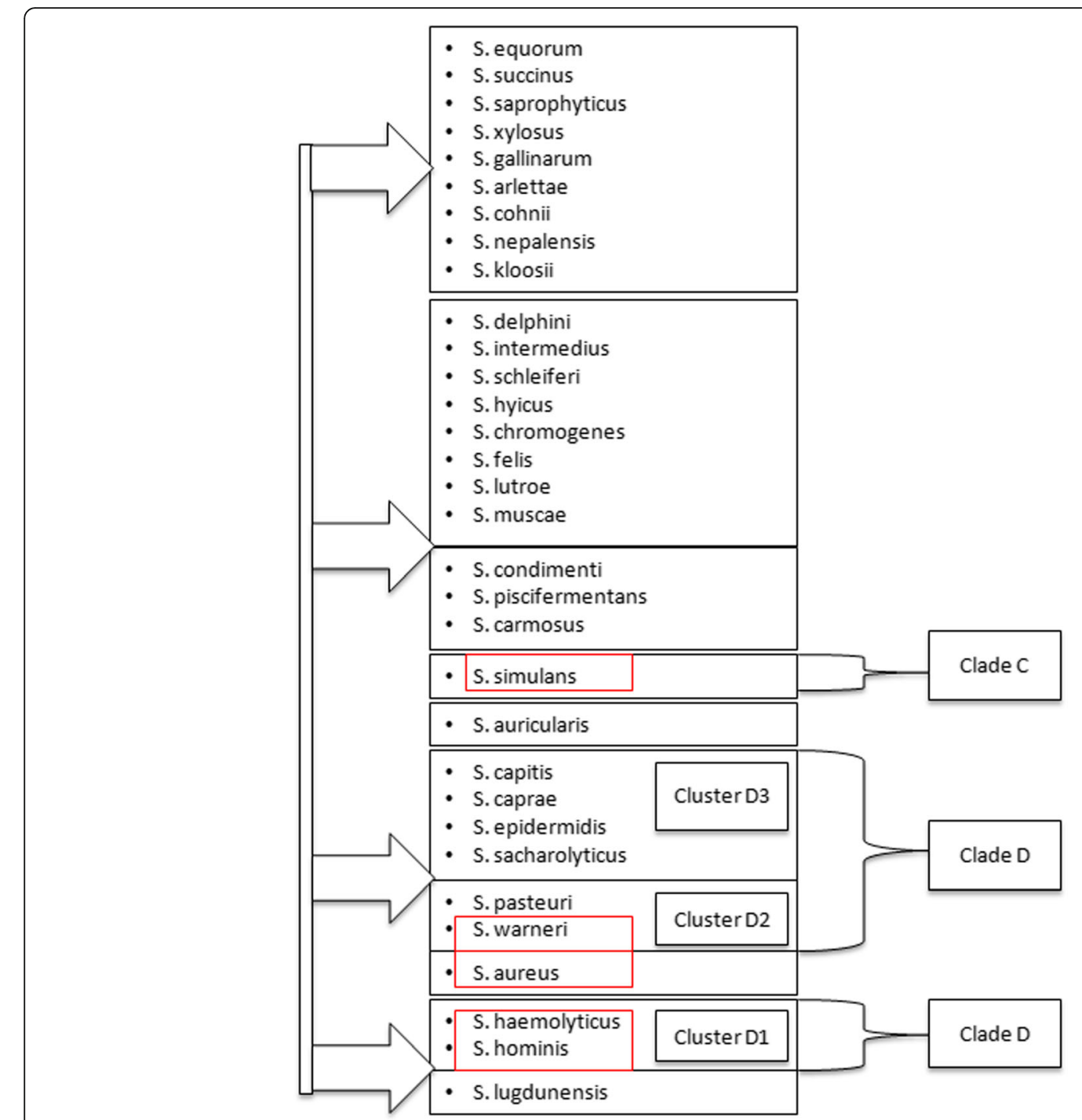

Fig. 2 Phylogenetic tree of the species similarities of the Staphylococcus genus (according to de Vos et al., (2009) and Naushad et.al (2017) with own modification) $[39,40]$

The spread of new clones with these properties in a hospital environment may make them the emerging pathogens among the CoNS. PVL secreted by $S$. aureus is linked to severe life-threatening infections e.g. osteomyelitis, often accompanied by deep vein thrombosis (DVT), especially in young patients [64, 65]. PVL is mostly related to community-associated methicillin-resistant $S$. aureus (CA-MRSA) infections, particularly of skin and soft tissue and to highly lethal necrotising pneumonia [66, 67]. The $p v l$ genes are located on lysogenised bacteriophages integrated into the $S$. aureus chromosome [68]. We detected also an expression of the enterotoxin gene sea in S. simulans and $S$. warneri isolates. SEA is the most common toxin causing $S$. aureus-related food poisoning [69]. The expression pattern of SEA is different from that of SEB, SEC, and SED, as it is regulated independently of the accessory gene regulator (Agr) [70]. Genes for SEA are located on the prophages, for SEB on the chromosome or plasmid, and for SEG and SEI on enterotoxin gene cluster $(e g c)$ and the chromosome. As most of these regions are mobile, horizontal transfer between the strains is possible [71, 72]. Among the tested isolates, we observed significant differences in their sensitivity to antibiotics. S. haemolyticus and $S$. hominis isolates were multi-resistant. These strains may have participated in transmission of genes related to the resistance of $S$. aureus [7, 73]. In our studies, the resistance of the tested $S$. haemolyticus isolates was equally represented by strains isolated from blood and other materials. All the $S$. hominis isolates tested by us belonged to $S$. hominis subsp. hominis and were resistant to all clinically important antibiotics. Up to now, another S. hominis subspecies, S. hominis subsp. novosepticus, was 
considered as multi-resistant [74]. Similarly to S. epidermidis, $S$. hominis is present on human skin more often than other CoNS [39]. They are numerous on the shoulders, legs, and the head. Together with their common multiresistance to antibiotics and the fact that they easily cause blood infections, this accounts for an additional biohazard. Among all the tested species, S. hominis isolates accumulated in the most efficient way the virulence genes typical for $S$. aureus; they were also the most resistant to antibiotics. What is important, the antibiotics of choice in the treatment for such serious infections caused by MRCoNS are vancomycin and daptomycin. In the study we did not mark MIC for such antibiotics.

The resistance to the tested antibiotics was less common among S. simulans and S. warneri isolates and concerned mainly macrolides, lincosamides aminoglycosides, and tetracyclines. Detailed data related to the resistance of the tested isolates to macrolides, lincosamides, and streptogramin B were presented in our previous paper [75].

The resistance to methicillin was an important feature of the S. haemolyticus and S. hominis isolates. Our results confirmed that rifampicin and fusidic acid could be applied as an alternative treatment of infections caused by methicillin-resistant CoNS [76]. According to studies related to MRSA, 11 types of SCCmec cassettes have been described (International Working Group on the Classification of Staphylococcal Cassette Chromosome Elements, 2009) [35]. It is suggested that their diversity in CoNS may even be much higher [77]. In S. haemolyticus isolates, we detected type $\mathrm{V}$ cassettes, which are described in the literature as typical for this species $[78,79]$. Moreover, we observed the presence of mec complex $C$ and $c c r$ complex $C$ in these isolates, while their presence in other tested species was occasional. Among S. hominis species, mec complex $A$ and $c c r$ complex $A B 1$ were the most common. Such a combination of mec and $c c r$ complexes does not correspond to any of the so far described cassettes. Other authors also confirmed the existence of this combination among the strains of $S$. hominis, also with a link to the $c \mathrm{cr}$ complex $C[9,77,80]$. The cassette type that was marked in our studies as 'NEW' and was found in S. haemolyticus and $S$. hominis isolates, was a new configuration containing the mec complex $A$ with the combination of the $c c r$ complex $C$ or the $c c r$ complex $A B 1$. Data related to the presence of SCCmec in S. simulans and S. warneri species are sparse [81, 82]. Our results broaden this knowledge. We detected type IV cassette containing the $c c r$ complex $A B 2$ or the mec complex $A$ in $S$. warneri and a new combination (NEW) in other isolates.

\section{Conclusions}

Our results highlight the increasing significance of CoNS. To the best of our knowledge, the study is the first report that indicates differences among the four tested CoNS species, less frequently isolated from human clinical specimens. The study also shows that staphylococci, mainly isolated from blood, are a serious threat for the patients. These bacteria are multi-resistant to antibiotics, which causes additional difficulties in treatment. Presented data shows that infections caused by CoNS should be a cause of concern to the clinicians. Taking into consideration that bacteremia caused by MRCoNS is treated by vancomycin and daptomycin, marking the sensitivity for these antibiotics is a target for future studies.

\section{Abbreviations}

CC: Clindamycin; CIP: Ciprofloxacin; CoNS: Coagulase-negative staphylococci; E: Erythromycin; FA: Fusidic acid; FOX: Cefoxitin; GM: Gentamicin; LZD: Linezolid; RA: Rifampicin; SXT: Cotrimoxazole; TE: Tetracycline; TGC: Tigecycline

\section{Acknowledgements}

We would like to thank Maria Sobiś Glinkowska for support in marking of the ability to produce lipases in tested strains. We also thank Tomasz Czekaj for his contribution in an $\mathrm{SCCmec}$ analysis.

\section{Authors' contributions}

All authors designed the experiments. MSz, MG and EB performed the experiments. MSz, MG and ESz analyzed the data. MSz, MG and ESz wrote the manuscript. All authors read and approved the manuscript.

\section{Funding}

This study was supported by the statutory research funds (502-03/3-012-03/ 503-31-011) of the Medical University of Lodz.

\section{Availability of data and materials}

The datasets used and/or analyzed during the current study are available from the corresponding author on reasonable request.

\section{Ethics approval and consent to participate}

Not applicable. In the study, informed consent was not required as the isolates included in the study were obtained as a result of standard medical care. Patient identity as well as all the personal information were confidential.

Consent for publication

Not applicable.

\section{Competing interests}

The authors declare that they have no competing interests.

\section{Author details}

'Department of Pharmaceutical Microbiology and Microbiological Diagnostic, Medical University of Lodz, Pomorska 137, 90-235 Łódź, Poland. ${ }^{2}$ Department of Pharmaceutical Biochemistry and Molecular Diagnostic, Laboratory of Molecular Diagnostic and Pharmacogenomics, Medical University of Lodz, Łódź, Poland.

Received: 4 September 2019 Accepted: 31 January 2020

Published online: 11 February 2020

\section{References}

1. Lamers RP, Muthukrishnan G, Castoe TA, Tafur S, Cole AM, Parkinson CL. Phylogenetic relationships among Staphylococcus species and refinement of cluster groups based on multilocus data. BMC Evol Biol. 2012;12:171.

2. Barros EM, Lemos M. Souto-Padro'n T, Giambiagi-deMarval M. phenotypic and genotypic characterization of biofilm formation in Staphylococcus haemolyticus. Curr Microbiol. 2015;70(6):829-34.

3. Hitzenbichler F, Simon M, Salzberger B, Hanses F. Clinical significance of coagulase-negative staphylococci other than S. epidermidis blood stream isolates at a tertiary care hospital. Infection. 2017;45(2):179-86. 
4. Panda S, Singh DV. Biofilm formation by Ica-negative ocular isolates of Staphylococcus haemolyticus. Front Microbiol. 2018;9:2687.

5. Takeuchi F, Watanabe S, Baba T, Yuzawa H, Ito T, Morimoto Y, et al. Wholegenome sequencing of Staphylococcus haemolyticus uncovers the extreme plasticity of its genome and the evolution of human-colonizing staphylococcal species. J Bacteriol. 2005;187(21):7292-308.

6. Barros EM, Ceotto H, Bastos MCF, Dos Santos KRN, Giambiagi-Demarval M. Staphylococcus haemolyticus as an important hospital pathogen and carrie of methicillin resistance genes. J Clin Microbiol. 2012;50(1):166-8.

7. Czekaj T, Ciszewski M, Szewczyk EM. Staphylococcus haemolyticus - an emerging threat in the twilight of the antibiotics age. Microbiology. 2015; 161(11):2061-8.

8. Al Wohoush I, Rivera J, Cairo J, Hachem R, Raad I. Comparing clinical and microbiological methods for the diagnosis of true bacteraemia among patients with multiple blood cultures positive for coagulase-negative staphylococci. Clin Microbiol Infect. 2011;17(4):569-71.

9. Mendoza-Olazarán S, Morfin-Otero R, Rodríguez-Noriega E, Llaca-Díaz J, Flores-Treviño S, González-González GM, Villarreal-Treviño L, Garza-González E. Microbiological and molecular characterization of Staphylococcus hominis isolates from blood. PLoS One. 2013;8(4):e61161.

10. Frickmann $H$, Hahn A, Skusa R, Mund N, Viehweger $V$, Köller T, et al. Comparison of the etiological relevance of Staphylococcus haemolyticus and Staphylococcus hominis. Eur J Clin Microbiol Infect Dis. 2018;37(8):1539-45.

11. Peel TN, Cheng AC, Buising KL, Choong PF. Microbiological aetiology, epidemiology, and clinical profile of prosthetic joint infections: are current antibiotic prophylaxis guidelines effective? Antimicrob Agents Chemother. 2012;56(5):2386-91.

12. von Eiff C, Arciola CR, Montanaro L, Becker K, Campoccia D. Emerging Staphylococcus species as new pathogens in implant infections. Int J Artif Organs. 2006;29(4):360-7.

13. Zimmerli W, Trampuz A, Ochsner PE. Prosthetic-joint infections. N Engl J Med. 2004;351:1645-54.

14. Mohan N, lyer MN, Wirostko WJ, Kim SH, Simons KB. Staphylococcus hominis endophthalmitis associated with a capsular hypopyon. Am J Ophthalmol. 2005;139(5:930-2.

15. Kline DA. Staphylococcus simulans osteomyelitis of the foot: a case report. Foot Ankle Online J. 2010;3(1):4.

16. Marrie TJ, Kwan C, Noble MA, West A, Duffield L. Staphylococcus saprophyticus as a cause of urinary tract infections. J Clin Microbiol. 1982;16(3):4.

17. Shields BE, Tschetter AJ, Wanat KA. Staphylococcus simulans: an emerging cutaneous pathogen. JAAD Case Rep. 2016;2(6):428-9.

18. Vallianou N, Evangelopoulos A, Makri P, Zacharias G, Stefanitsi P, Karachalios A, Avgerinos PC. Vertebral osteomyelitis and native valve endocarditis due to Staphylococcus simulans: a case report. J Med Case Rep. 2008;2:183.

19. Barnham M, Horton R, Smith JMP, Richardson J, Marples RR, Reith S. Methicillin-resistant Staphylococcus simulans masquerading as MRSA in a nursing home. J Hosp Infect. 1996:34(4):331-7.

20. Torre D, Ferraro G, Fiori GP, Martegani R, Speranza F, Tambini R, Zeroli C. Ventriculatrial shunt infection caused by Staphylococcus warneri: case report and review. Clin Infect Dis. 1992;14(1):49-52.

21. Ivić I, Karanović J, Pavičić-Ivelja M. Sepsis with multiple abscesses caused by Staphylococcus warneri: a case report. Cent Eur J Med. 2013;8(1):45-7.

22. Campoccia D, Montanaro L, Visai L, Corazzari T, Poggio C, Pegreffi F, et al. Characterization of 26 Staphylococcus warneri isolates from orthopedic infections. Int J Artif Organs. 2010;33(9):575-81.

23. Cimiotti JP, Haas JP, Della-Latta P, Wu F, Saiman L, Larson EL. Prevalence and clinical relevance of Staphylococcus warneri in the neonatal intensive care unit. Infect Control Hosp Epidemiol. 2007;28(3):326-30.

24. Ohara-Nemoto $Y$, Haraga $H$, Kimura S, Nemoto TK. Occurrence of staphylococci in the oral cavities of healthy adults and nasal oral trafficking of the bacteria. J Med Microbiol. 2008;57(1):95-9.

25. Shin JH, Kim SH, Jeong HS, Oh SH, Kim HR, Lee JN, Yoon YC, Kim YW, Kim $\mathrm{YH}$. Identification of coagulase-negative staphylococci isolated from continuous ambulatory peritoneal dialysis fluid using 16S ribosomal RNA, tuf, and sodA gene sequencing. Perit Dial Int. 2011;31(3):340-6.

26. Spanu T, Sanguinetti M, Ciccaglione D, D'Inzeo T, Romano L, Leone F, Fadda G. Use of the VITEK 2 system for rapid identification of clinical isolates of staphylococci from bloodstream infections. J Clin Microbiol. 2003:41(9):4259-63.

27. Blaiotta G, Casaburi A, Villani F. Identification and differentiation of Staphylococcus carnosus and Staphylococcus simulans by species-specific PCR assays of sodA genes. Syst Appl Microbiol. 2005;28(6):519-26.
28. Hirotaki S, Sasaki T, Kuwahara-Arai K, Hiramatsu K. Rapid and accurate identification of human-associated staphylococci by use of multiplex PCR. J Clin Microbiol. 2011;49(10):3627-31.

29. Christensen GD, Simpson WA, Younger JJ, Baddour LM, Barrett FF. Melton Beachey EH. Adherence of coagulase-negative staphylococci to plastic tissue culture plates: a quantitative model for the adherence of staphylococci to medical devices. J Clin Microbiol. 1985;22(6):996-1006.

30. Kouker G, Jaeger KE. Specific and sensitive plate assay for bacterial lipases. Appl Environ Microbiol. 1987;53(1):211-3.

31. Zhang K, Mcclure J, Elsayed S, Louie T, Conly JM. Novel multiplex PCR assay for characterization and concomitant subtyping of staphylococcal cassette chromosome. Microbiology. 2005;43(10):5026-33.

32. Kondo $Y$, Ito T, Ma XX, Watanabe $S$, Kreiswirth BN, Etienne J, Hiramatsu K. Combination of multiplex PCRs for staphylococcal cassette chromosome mec type assignment: rapid identification system for mec, ccr, and major differences in junkyard regions. Antimicrob Agents Chemother. 2007;51(1):264-74.

33. Oliveira DC, Milheiriço $C$, De Lencastre $H$. Redefining a structural variant of staphylococcal cassette chromosome mec, SCCmec type VI. Antimicrob Agents Chemother. 2006;50(10):3457-9.

34. Zhang L, Thomas JC, Miragaia M, Bouchami O, Chaves F, d'Azevedo PA, et al. Multilocus sequence typing and further genetic characterization of the enigmatic pathogen, Staphylococcus hominis. 2013;8(6):PLoS One, e66496 2013

35. International Working Group on the Classification of Staphylococcal Cassette Chromosome Elements. Classification of staphylococcal cassette chromosome mec (SCCmec): guidelines for reporting novel SCCmec elements. Antimicrob Agents Chemother. 2009;53(12):4961-7.

36. Jarraud S, Mougel C, Thioulouse J, Lina G, Meugnier H, Forey F, Nesme X, Etienne J, Vandenesch F. Relationships between Staphylococcus aureus genetic background, virulence factors, agr groups (alleles), and human disease. Infect Immun. 2002;70(2):631-41.

37. Ünal N, Çinar OD. Detection of stapylococcal enterotoxin, methicillinresistant and Panton-valentine leukocidin genes in coagulase-negative staphylococci isolated from cows and ewes with subclinical mastitis. Trop Anim Health Prod. 2012;44(2):369-75.

38. Arciola CR, Gamberini S, Campoccia D, Visai L, Speziale P, Baldassarri L, Montanaro L. A multiplex PCR method for the detection of all five individual genes of Ica locus in Staphylococcus epidermidis. A survey of 400 clinical isolates from prosthesisassociated infections. J Biomed Mater Res. 2005;75(2):408-13.

39. de Vos P, Garrity G, Jones D, Krieg N, Ludwig W, Rainey F, Whitman SK, W. Berge's manual of determinative bacteriology. The Firmicutes. Dordrecgt Heidelberg, New York: Springer; 2009.

40. Naushad S, Barkema HW, Luby C, Condas LAZ, Nobrega DB, Carson DA, DeBuck J. Comprehensive phylogenetic analysis of bovine non-aureus staphylococci species basedon whole-genome sequencing. Front Microbiol. 2016;7:1990.

41. Even S, Leroy S, Charlier C, Zakour NB, Chacornac JP, Lebert I, et al. Low occurrence of safety hazards in coagulase negative staphylococci isolated from fermented food stuffs. Int J Food Microbiol. 2010;139(1-2):87-95.

42. Gao P, Wang Y, Villanueva I, Ho PL, Davies J, Kao RYT. Construction of a multiplex promoter reporter platform to monitor Staphylococcus aureus virulence gene expression and the identification of usnic acid as a potent suppressor of psm gene expression. Front Microbiol. 2016;7:1344.

43. Pinheiro L, Brito Cl, de Oliveira A, Martins PY, Pereira VC, da Cunha Mde L. Staphylococcus epidermidis and Staphylococcus haemolyticus: molecular detection of cytotoxin and enterotoxin genes. Toxins. 2015;7(9):3688-99.

44. Darouiche R. Device-associated infections: a macroproblem that starts with microadher- ence. Clin Infect Dis. 2001;33(9):1567-72.

45. Jain A, Agarwal A. Biofilm production, a marker of pathogenic potential of colonizing and commensal staphylococci. J Microbiol Methods. 2009;76(1):88-92.

46. Cardile AP, Sanchez CJ, Samberg ME Jr, Romano DR, Hardy SK, Wenke JC, Murray CK, Akers KS. Human plasma enhances the expression of staphylococcal microbial surface components recognizing adhesive matrix molecules promoting biofilm formation and increases antimicrobial tolerance in vitro. BMC Res Notes. 2014;7:457.

47. Fey PD. Modality of bacterial growth presents unique targets: how do we treat biofilm-mediated infections? Curr Opin Microbiol. 2010;13(5):610-5.

48. Mertens A, Ghebremedhin B. Genetic determinants and biofilm formation of clinical Staphylococcus epidermidis isolates from blood cultures and indwelling devises. Eur J Microbiol Immunol. 2013;3(2):111-9.

49. Vuong C, Kocianova S, Voyich JM, Yao Y, Fischer ER, DeLeo FR, Otto M. A crucial role for exopolysaccharide modification in bacterial biofilm formation, immune evasion, and virulence. J Biol Chem. 2004;279:54881-6. 
50. Ziebuhr W, Heilmann C, Geotz F, Meyer P, Wilms K, Straube E, Hacker J. Detection of the intercellular adhesion gene cluster (Ica) and phase variation in Staphylococcus epidermidis blood culture strains and mucosal isolates. Infect Immun. 1997;65(3):890-6.

51. Bowden MG, Visai L, Longshaw CM, Holland KT, Speziale P, Hook M. Is the GehD lipase from Staphylococcus epidermidis a collagen binding adhesin? Biol Chem. 2002;8(45):43017-23.

52. Coenye T, Peeters E, Nelis HJ. Biofilm formation by Propionibacterium acnes is associated with increased resistance to antimicrobial agents and increased production of putative virulence factors. Res Microbiol. 2007;158(4):386-92.

53. Burkhart CG. Clinical assessment of acne pathogenesis with treatment implications. Int Pediatr. 2003;18:14-9.

54. Bojar RA, Holland KT. Review: the human cutaneous microflora and factors controlling colonization. World J Microbiol Biotechnol. 2002;18(9):889-903.

55. Delekta PC, Shook JC, Lydic TA, Mulks MH, Hammer ND. Staphylococcus aureus utilizes host-derived lipoprotein particles as sources of exogenous fatty acids. J Bacteriol. 2018;200(11):e00728-17.

56. Rollof J, Hedström SA, Nilsson-Ehle P. Lipolytic activity of Staphylococcus aureus strains from disseminated and localized infections. Acta Pathol Microbiol Immunol Scand B. 1987;95(2):109-13.

57. Parsons JB, Frank MW, Subramanian C, Saenkham P, Rock CO. Metabolic basis for the differential susceptibility of gram-positive pathogens to fatty acid synthesis inhibitors. Proc Natl Acad Sci U S A. 2011;108(37):15378-83.

58. van Kampen MD, Rosenstein R, Götz F, Egmond MR. Cloning, purification and characterisation of Staphylococcus warneri lipase 2. Biochim Biophys Acta. 2001;1544(1-2):229-41.

59. Rosenstein R, Götz F. Staphylococcal lipases: biochemical and molecular characterization. Biochimie. 2000:82(11):1005-14.

60. Simons JW, van Kampen MD, Riel S, Götz F, Egmond MR, Verheij HM. Cloning, purification and characterisation of the lipase from Staphylococcus epidermidis-comparison of the substrate selectivity with those of other microbial lipases. Eur J Biochem. 1998;253(3):675-83.

61. Lina G, Bohach GA, Nair SP, Hiramatsu K, Jouvin-Marche E, Mariuzza R. International nomenclature Committee for Staphylococcal Superantigens. Standard nomenclature for the superantigens expressed by staphylococcus. J Infect Dis. 2004;189(12):2334-6.

62. Lina G, Piémont Y, Godail-Gamot F, Bes M, Peter MO, Gauduchon V, Vandenesch F, Etienne J. Involvement of Pan ton-valentine leukocidinproducing Staphylococcus aureus in primary skin infections and pneumonia. Clin Infect Dis. 1999;29(5):1128-32.

63. Prevost G, Couppie P, Prevost P, Gayet S, Petiau P, Cribier B, Monteil H, Piemont Y. Epidemiological data on Staphylococcus aureus strains producing synergohymenotropic toxins. J Med Microbiol. 1995;42(4):237-45.

64. Gonzalez BE, Teruya J, Mahoney DH Jr, Hulten KG, Edwards R, Lamberth LB, Hammerman WA, Mason EO Jr, Kaplan SL. Venous thrombosis associated with staphylococcal osteomyelitis in children. Pediatrics. 2006;117(5):1673-9.

65. Sheikh HQ, Aqil A, Kirby A, Hossain FS. Panton-valentine leukocidin osteomyelitis in children: a growing threat. Br J Hosp Med (Lond). 2015;76(1):18-24.

66. Gillet $Y$, Issartel B, Vanhems P, Fournet JC, Lina G, Bes M, et al. Association between Staphylococcus aureus strains carrying gene for Panton-valentine leukocidin and highly lethal necrotising pneumonia in young immunocompetent patients. Lancet. 2002;359(9308):753-9.

67. Shallcross $L$, Fragaszy $E$, Johnson AM, Hayward AC. Te role of the Pantonvalentine leucocidin toxin in staphylococcal disease: a systematic review and meta-analysis. Lancet Infect Dis. 2013;13(1):43-54.

68. David MZ, Daum RS. Community-associated methicillin-resistant Staphylococcus aureus: epidemiology and clinical consequences of an emerging epidemic. Clin Microbiol Rev. 2010;23(3):616-87.

69. Schmitz FJ, MacKenzie CR, Geisel R, Wagner S, Idel H, Verhoef J, Hadding U, Heinz HP. Enterotoxin and toxic shock syndrome toxin-1 production of methicillin resistant and methicillin sensitive Staphylococcus aureus strains. Eur J Epidemiol. 1997;13(6):699-708.

70. Tremaine MT, Brockman DK, Betley MJ. Staphylococcal enterotoxin a gene (sea) expression is not affected by the accessory gene regulator (agr). Infect Immun. 1993;61(1):356-9.

71. Omoe K, Hu DL, Takahashi-Omoe H, Hanane A, Shinagawa K. Comprehensive analysis of classical and newly described staphylococcal superantigenic toxin genes in Staphylococcus aureus isolates. FEMS Microbiol Lett. 2005;246(2):191-8.

72. Pinchuk IV, Beswick EJ, Reyes VE. Staphylococcal enterotoxins. Toxins. 2010; 2(8):2177-97.
73. Fluit AC, Carpaij N, Majoor EA, Bonten MJM, Willems RJL. Shared reservoir of ccrB gene sequences between coagulase-negative staphylococci and methicillin-resistant Staphylococcus aureus. J Antimicrob Chemother. 2013; 68(8):1707-13.

74. Kloos WE, George CG, Olgiate JS, Van Pelt L, McKinnon ML, Zimmer BL, Muller E, Weinstein MP, Mirrett S. Staphylococcus hominis subsp. novobiosepticus subsp. nov. a novel trehaloseand N-acetyl-D-glucosaminenegative, novobiocin-and multiple-antibiotic-resistant subspecies isolated from human blood cultures. Int J Syst Bacteriol. 1998;48(3):799-812.

75. Szemraj M, Czekaj T, Kalisz J, Szewczyk EM. Differences in distribution of MLS antibiotics resistance genes in clinical isolates of staphylococci belonging to species: S. epidermidis, S. hominis, S. haemolyticus, S. simulans and S. warneri. BMC Microbiol. 2019;19:124.

76. Soumya K, Roopashree S, Balasubrahmanya HV. Prevalence and antibiogram of methicillin resistant Staphylococcus aureus in a tertiary care Centre in Tumkur. India Int J Curr Microbiol App Sci. 2017;6(9):2236-43.

77. Martínez-Meléndez A, Morfín-Otero R, Villarreal-Treviño L, González-González G, Llaca-Díaz J, Rodríguez-Noriega E, Camacho-Ortíze A, Garza-González E. Staphylococcal cassette chromosome mec (SCCmec) in coagulase negative staphylococci. Med Univ. 2015;17(69):229-33.

78. Panda S, Kar S, Sharma S, Singh DV. Multidrug-resistant Staphylococcus haemolyticus isolates from infected eyes and healthy conjunctivae in India. J Glob Antimicrob Resist. 2016;6:154-9.

79. Szczuka E, Kaznowski A. Zróżnicowanie kaset SCCmec u metycylinoopornych gronkowców koagulazo-ujemnych. Postępy Mikrobiol. 2014;53(3):223-8.

80. Mendoza-Olazarán S, Morfin-Otero R, Villarreal-Trevino L, Rodriguez-Noriega E, Llaca-Diaz J, Camacho-Ortiz A, González GM, Casillas-Vega N, GarzaGonzález E. Antibiotic susceptibility of biofilm cells and molecular characterisation of staphylococcus hominis isolates from blood. PLoS One. 2015;10(12):1-13.

81. Silva NCC, Guimarães FF, Manzi MDP, Gómez-Sanz E, Gómez P, Araújo JP, Langoni H, Rall VL, Torres C. Characterization of methicillin-resistant coagulase-negative staphylococci in milk from cows with mastitis in Brazil. Antonie Van Leeuwenhoek. 2014;106(2):227-33.

82. Zong Z, Peng C, LüX. Diversity of SCCmec elements in methicillin-resistant coagulase-negative staphylococci clinical isolates. PLoS One. 2011;6(5):1-6.

\section{Publisher's Note}

Springer Nature remains neutral with regard to jurisdictional claims in published maps and institutional affiliations.

Ready to submit your research? Choose BMC and benefit from:

- fast, convenient online submission

- thorough peer review by experienced researchers in your field

- rapid publication on acceptance

- support for research data, including large and complex data types

- gold Open Access which fosters wider collaboration and increased citations

- maximum visibility for your research: over $100 \mathrm{M}$ website views per year

At $\mathrm{BMC}$, research is always in progress.

Learn more biomedcentral.com/submission 